\title{
E-electioneering 2007-2013: Trends in online political campaigns over three elections
}

\author{
Jim Macnamara \\ University of Technology Sydney \\ Gail Kenning \\ University of Technology Sydney
}

\begin{abstract}
Following the 2004 US presidential election campaign, which was described as 'a critical turning point' in use of social media, and particularly the 2008 Obama campaign, there has been increasing focus on use of social media for political campaigning and what is termed $e$ electioneering and e-democracy. However, studies of election campaigns between 2010 and 2012 in a number of countries have identified what Steve Woolgar (2002) calls cyberbole in relation to social media for political engagement. With substantive patterns of change in political communication yet to be identified, a quantitative and qualitative study of social media use in the 2013 Australian federal election campaign was conducted using the same methodology as studies of the 2007 and 2010 campaigns to gain comparative longitudinal data. This identified trends in the volume of e-electioneering and the ways in which social media are being used for political communication and democratic engagement.
\end{abstract}

\section{Introduction}

Even though Australia has compulsory voting, which means that voter mobilisation is not a primary election campaign strategy (Gibson, Lusoli and Ward , 2008), Australian political parties and candidates have followed international trends in embracing the Web and social media for encouraging voter participation and election campaigning, as shown by Chen (2008), Flew and Wilson (2008), Gibson, Lusoli and Ward (2008), Gibson and McAllister (2008), Gibson and Ward (2008), Goot (2008), Macnamara (2008, 2011) and others.

Xenos and Moy described the 2004 US presidential election as 'a critical turning point' when online politics 'finally reached a mainstream audience' (2007: 704). Subsequently, a number of studies were made of social media use in national elections in the US (e.g., Rainie, Smith, Schlozman et al., 2012; Smith and Rainie, 2008); the UK (e.g., Gibson, Cantijoch and Ward, 2010; Gibson, Williamson and Ward, 2010); Australia, and other countries such as Sweden (Karlsson, Clerwall and Buskquist, 2012) and Taiwan (Lin, 2013) between 2007 and 2012.

Bold pronouncements have been made in popular discourse in Australia as well as in the US, UK and other countries about social media transforming the face of political campaigning and communication, such as claims of 'the YouTube election' (Media Monitors, 2008; Sydney Morning Herald, 2007), a 'Google election' (Gibson and Ward, 2008), an 'internet election' (Gibson, Williamson and Ward, 2010: 1) and a 'social media election' (Smith, 2013). However, Gibson and McAllister (2008a) noted that the promise of social media reaching a mainstream audience reported by Xenos and Moy (2007) was unfulfilled in the 2007 Australian federal election, a contention supported by Macnamara (2008). Similarly, in their detailed analysis of the 2010 UK election, Gibson, Williamson and Ward concluded: 
Whilst the UK parties arguably began to understand some of the significance of e-campaigning they still failed to fully buy into [the] concept. They still either operated an old-fashioned, topdown broadcasting principles (Conservatives) or only sporadically linked online mobilisation to offline activity (Labour) (2010: 3).

In a comparative analysis of the 2010 UK and Australian election campaigns, Gibson and Cantijoch reported that, while there was increased openness and commitment to Web 2.0 techniques among British political parties, they 'tended to give priority to the more top-down Web 1.0 applications that are aimed mainly at broadcasting information'. They added that, overall, there was 'an adherence to the unidirectional flows of Web 1.0 communication' (2011: 9)

A study of social media use by Sweden's 10 political parties at nine intervals over the period of the 2010 Swedish national election campaign by Karlsson, Clerwall and Buskquist (2012) found that all parties had official pages on Facebook, YouTube channels and Twitter accounts and most had blogs and Flickr sites. However, they reported that 'although the parties make room for user input to some extent', there was interaction between the political parties and citizens in fewer than half of the postings studied and 'there was only one-way traffic on other occasions' (2012: 17).

From a mixed method study involving interviews with the campaign staff of both presidential candidates and analysis of social media content during the 2010 Taiwan national election, Lin concluded that 'interaction between candidates and netizens is limited', although he noted that there was 'interplay' between top-down and bottom-up power on popular social media sites in Taiwan such as Plurk (2013: 303).

Despite many transformational claims made in relation to the 2008 and 2012 Obama campaigns, a Pew Research Center study reported that 'neither campaign made much use of the social aspect of social media. Rarely did either candidate [or their team of staff] reply to, comment on, or "retweet” something from a citizen - or anyone else outside the campaign' (Rosenstiel \& Mitchell, 2012: 3). The Pew report, sub-titled 'Obama leads but neither candidate engages in much dialogue with voters', also noted that party campaign Web sites remained primarily one-way transmissional in nature.

Nevertheless, because of declining citizen interest and participation in traditional politics and political communication (Dahlgren, 2009; McAllister, 2002), declining citizens' trust in politicians and traditional representative institutions (Coleman, 2013; Gibson, Lusoli and Ward, 2008: 111-113) and declining audiences of many traditional mass media referred to as 'audience fragmentation' (Anderson, 2006: 181-91; Jenkins, 2006: 238-43), politicians and political parties continue to look for new ways to engage voters and address what researchers refer to as the 'democratic deficit' (Couldry, 2010: 49; Curran, 2011: 86). In particular, political parties and governments are concerned that 'younger generations have disconnected from conventional politics and government in alarming numbers' (Bennett, 2008: 1) and government agencies such as the Australian Electoral Commission are seeking ways to increase the engagement of young people in political participation (Macnamara, Sakinofsky and Beattie, 2012).

The 2013 Australian federal election provided an opportunity to examine the use of social media and online engagement by political candidates and parties and compare findings with those of similar studies of the 2007 and 2010 federal election campaigns. In addition, with social media use in US presidential campaigns being largely focussed on fund-raising and gaining voter turnout because of voluntary voting (Scherer, 2012; Vargas, 2008), Australian 
election campaigns provide useful sites to examine social media use focussed primarily on e-electioneering and e-democracy.

\section{Understanding social media and e-democracy: The frame for analysis}

Kaplan and Haenlein (2010) define social media as 'a group of internet-based applications that build on the ideological and technological foundations of Web 2.0 and that allow the creation and exchange of user generated content' (2010: 61). This provides a useful theoretical starting point for an examination of the use of social media, as it indicates that social media are characterized by a particular ideology, not only technology - or what other researchers and pioneers of the World Wide Web, and particularly Web 2.0, refer to as a philosophy, principles, protocols and culture, particularly pointing to openness and interactivity (Jenkins, 2006; Merholz, 2005; O’Reilly, 2005).

Boler notes that the founder of the World Wide Web, Tim Berners-Lee, said the Web was designed for 'shared creativity' and was never intended to be about delivering content to passive audiences (2008: 39). In this sense, uses of the Web for static content and one-way transmission of information - commonly referred to as Web 1.0 (Vergeer, 2013) - can be seen as a misuse and a continuation of mass media practices. The term Web 2.0 was coined by Tim O'Reilly in 2004 to refer to Web-based services that feature openness for participation, collaboration and interactivity (Boler, 2008: 39; O’Reilly, 2005).

The characteristics of Web 2.0 have been explicated by a number of researchers including Jenkins who emphasised in Convergence Culture that Web 2.0 is about culture more than technology and, in particular, 'participatory culture' (2006: 243). Harrison and Barthel state that 'Web 2.0 is founded on a radical reconceptualization of the user, from consumer of online products and information ... to producer of online products and information that they share with others' (2009: 160). Interactivity is also emphasised by Bucy (2004) and Cover (2004) as a defining element of Web 2.0 communication - in particular, user-to-user interactivity (McMillan, 2002: 166-72), or what Stromer-Galley (2000a) calls 'humaninteractive features', rather than the more narrow and perfunctory level of user-to-system interactivity. Carpentier similarly advocates what he calls 'person-to-person' interactivity versus 'person-to-machine' interaction (2007: 221). In a political context, Xenos, Vromen and Loader noted that 'Web 2.0 functionalities' and 'the unique properties of social media' overcome key limitations of Web 1.0, potentially making it easier for individuals to participate in traditional and non-traditional acts of political participation (2014: 154).

Based on the literature in relation to Web 2.0 and social media, this analysis examined qualitative criteria in online political communication including openness and interactivity that enable sharing, dialogue, conversation and participation, as well as evaluating the volume of social media use by political candidates and parties. Also, this analysis was informed by the definitions and descriptions of Web 2.0 as being about relinquishing control that characterises one-way, top-down information distribution (Bucy, 2004; Boler, 2008; Jenkins, 2006; Macnamara, 2014: 42).

Political and social science scholars widely agree that media collectively comprise the primary discursive site of the public sphere in contemporary democracies (e.g., Carpentier, 2011; Curran, 2011, 2012; Habermas, 2006; Howley, 2007). Notwithstanding a number of limitations of online media such as the 'digital divide' between those with ready access to new digital media and those without because of socioeconomic, cultural or other factors (Gandy, 2002; Hoffman and Novak, 1998), many harbour great hopes for a revitalisation of the public sphere and redress of the 'democratic deficit' through online communication and 
participation (Jenkins, 2006; Flew, 2014: 199). Corner says many see the internet, particularly Web 2.0 type interactive communication, 'bypassing ... the degraded central systems of mediation in favour of a more independent, varied and critical range of resources for political knowledge' (2007: 223).

It has to be noted that, despite such optimism for the past two decades, a number of studies have found that not much has changed in institutionalised politics since development of the Web and even since the growing popularity of Web 2.0. Stromer-Galley noted that studies in the US through the 1990s found that political candidates generally did not use the internet for public discussions (2000b: 39) and, in another review, concluded that political candidates mostly seek to avoid online interaction (2000b). While these reviews were pre-Web 2.0, a recent analysis by Vergeer also concluded that the conduct of election campaigns 'has not changed drastically' (2013: 10). Hence, one has to approach studies of online interactivity and participation in election campaigns with some caution and even cynicism.

Nevertheless, with many forms of the most popular and potentially interactive social media still relatively 'new' (Flew, 2014; Siapera, 2012), continuing studies are important. For example, a study of 189 politicians using Twitter in the 2012 South Korea national election by Hwang (2013) found that Twitter use can create more positive perceptions of politicians and politics among young people (18-24 year olds) - a group of particular concern in terms of political engagement. Hwang reported that, in addition to creating a perception of politicians and politics as being more contemporary and up-to-date, use of Twitter indicated a desire for 'dialogic communication' and 'engagement' which improved the perceived credibility of and attitudes towards politicians and politics (Hwang, 2013: 254-55). It may be that politicians and major political parties are only beginning to recognise and embrace the benefits and the philosophy, culture, principles and protocols of social media?

Or it may be that incumbent politicians and major political parties do not yet realise the seriousness of public disenchantment and disengagement from traditional politics in major democracies and the need to change how we 'do politics'. In his recent book How Voters Feel, Coleman (2013) reported three important conclusions about elections. He observed that 'moments of voting are remarkably fleeting', the event of voting 'seems curiously socially disconnected' taking place in 'impersonal spaces ... devoid of ... registers of intimacy' and 'acts of voting are surrounded by an eerie silence' and a 'pervasive hush' 2013: 3). He noted that elections and voting were predominantly understood and assessed in terms of 'instrumental effectiveness' (2013: 4). Coleman argued that 'the sustainability of any cultural practice depends to a large measure on how it feels to participate in it' and added that 'the way in which politics in general, and voting in particular, are conducted is incongruent with the sensibilities of citizens as rational and emotional makers of meaning' (2013: 5). In short, voting and democratic politics in general do not affectively engage citizens; they pay no attention to how citizens feel. To most citizens, Coleman says 'the rules of the political game seem too much like imposed rules and someone else's game'. He concluded that there is an 'affective deficit' in contemporary democratic politics which is largely responsible for the disenchantment and disengagement, or stoic resignation at best, which characterise voting and attitudes towards politics in many democratic countries.

Coleman's analysis is significant and timely because, as well as being attractive to youth, social media sites afford opportunities for affective engagement - although this is often expressed pejoratively and as a criticism. Coleman noted that many claim that people using social media networks to express ideas and sentiments are engaged in 'senseless collective prattle’ (2013: 220). Papacharissi (2007), Fenton (2012), Vergeer (2013) and others have reported that a substantial proportion of social media use is personal and entertainment- 
orientated, and McNair has observed that social media are a 'more crowded, noisy, chaotic, competitive, and rancorous communications space than was envisaged for the modernist public sphere' (2006: 73).

But this may well be social media's key contribution to democratic politics - and perhaps even its saviour. Social media provide sites for subjective, personal and affective engagement; an engagement in politics on citizens' terms, rather than what Coleman calls democratic practice 'dominated by a discourse of arid proceduralism' (2013: 192). In contrast with the normative and increasingly unrealised notions of dutiful citizens (Schudson, 1998, 2003) engaged in minimalist democratic participation (Carpentier, 2011) in the normative deliberative public sphere proposed by Habermas (1989, 2006), interactive online sites and social media appeal to actualising citizens (Bennett, Wells and Freelon, 2011) who seek maximalist participation in personalised and often agonistic ways that Mouffe (1999) and others argue are more accessible and more attuned to the way people interact and engage. Mouffe says 'far from jeopardising democracy, agonistic confronting is in fact its very condition of existence', as it allows diverse viewpoints to be heard and gain consideration (1999: 756).

Xenos et al.'s reference to social media facilitating non-traditional as well as (or even more than) traditional political participation is salutary and a number of researchers rightly point to the activities of actualising citizens engaging in politics in personalised non-traditional ways as sites for further research (e.g., Bennett et al., 2011; Loader, Vromen and Xenos, 2014). However, it remains important to monitor and analyse the practices of dominant political actors and the traditional public sphere and, as noted in the introduction, Australian election campaigns afford ideal sites to examine the unfolding use of social media by elected politicians and major political parties. Furthermore, with quantitative and qualitative data available on the use of social media in the 2007 and 2010 Australian federal elections from previous studies (Macnamara, 2008; Macnamara and Kenning, 2011), the 2013 Australian federal election presented an opportunity to gain comparative longitudinal information to help identify trends in e-electioneering and e-democracy.

\section{Methodology of this study}

\section{Research questions}

This study took a socio-political rather than an information science approach and was designed to explore five research questions, the first two of which required quantitative analysis, while questions 3-5 involved qualitative analysis:

1. What social media were used by Australian politicians and political parties during the 2013 federal election campaign?

2. To what extent did incumbent Australian politicians and major political parties use social media during the 2013 federal election campaign in terms of volume and frequency?

3. To what extent did citizens engage with the studied politicians and political parties in social media during the 2013 federal election campaign (as evidenced through 'liking', 'following' and tagging political sites; viewing and downloading content; posting comments; retweeting; etc.)?

4. To what extent did the Australian politicians and political parties studied seek to engage and interact with citizens during the 2013 federal election campaign, as evidenced through interactive features on their sites (e.g., e-surveys; e-petitions; comment boxes; 'liking', 'following' and 'tagging' others' sites and content; viewing others' content; responding to comments, posts and tweets, etc.)? 
5. What were the main topics, issues and themes discussed on the social media sites studied during the campaign?

\section{Research method}

This mixed method study used quantitative and qualitative content analysis of social media including. In addition, based on the concept of Web 2.0 as outlined, interactive content on personal Web sites including e-petitions, e-surveys and e-newsletters was included in the study.

In the first stage, quantitative content analysis produced metrics on the volume of sites, blog posts, Facebook posts, tweets, retweets, videos posted online, video views, photos posted, comments, friends, likes, followers, following, views, downloads, tagging and links. These data were recorded and analysed in a series of Excel worksheets, including comparative analysis with equivalent 2007 and 2010 data.

Qualitative content analysis was focussed on the sites of the 'top 10' most active politicians on Twitter. Twitter was selected as the site for qualitative analysis because it is the fastest growing social media used by Australian politicians and political parties and also because it offers the most opportunities for interactivity, dialogue and participation, noting that most political Facebook accounts are 'pages' which do not allow posts by visitors (only likes) and few candidates' or party blogs published posts by anyone other than the site host, as will be discussed in reporting findings. Qualitative analysis of tweets was undertaken using NVivo Ncapture to import the text and metadata into NVivo 10 where they were coded, as recommended by text and content analysis scholars such as Neuman (2006) and Shoemaker and Reese (1996). Key words in the content of tweets, as well as metadata such as addressee and date sent, were used to code tweets into a number of categories which included identifying whether they were broadcasts, responses or direct messages, identifying the major topics discussed, and grouping them into a number of types including 'policy announcement', 'campaign slogan', 'attacking opponents', 'whereabouts reports', 'personal information or feelings', 'supporting colleague or party' and 'links to media articles or documents'. Coding categories are shown in Table 5.

\section{Sample}

To obtain data that were directly comparable with analysis of the 2007 and 2010 Australian federal election campaigns, the sample selected for analysis of social media use was based on all incumbent federal politicians standing for re-election in 2013 to the 150-member House of Representatives and the 76-member Senate in the Australian Parliament, as well as the two major political parties - the Australian Labor Party and the Liberal Party of Australia. This produced a sample of more than 1,000 social media sites of 191 politicians who averaged five or more Web sites each, as well as multiple sites of the two largest political parties. The remaining 35 sitting members were not standing for re-election.

\section{Period of research}

Quantitative and qualitative analysis were conducted of all sites in the sample during the final three weeks of the 2013 election campaign from Sunday 18 August to the close of polls at $6 \mathrm{pm}$ on Saturday 7 September. 


\section{Quantitative findings}

\section{Overview}

After social media use by federal politicians more than doubled between 2007 and 2010, the number of social media sites used by federal politicians increased by 67 per cent in 2013 compared with 2010. This represented a 243 per cent increase overall in social media use compared with the 2007 federal election, as shown in Table 1 along with a breakdown of the main types of social media and interactive online content used.

Table 1. Change in the number of politicians using various social media from 2007 to 2013.

\begin{tabular}{lrrrrr}
\hline Social media & $\mathbf{2 0 0 7}$ & $\mathbf{2 0 1 0}$ & $\mathbf{2 0 1 3}$ & $\begin{array}{r}\text { \% change } \\
\mathbf{2 0 1 0 - 2 0 1 3}\end{array}$ & $\begin{array}{r}\text { \% change } \\
\mathbf{2 0 0 7 - 2 0 1 3}\end{array}$ \\
\hline Personal Web site & 137 & 157 & 174 & $11 \%$ & $\mathbf{2 7 \%}$ \\
\hline Facebook & 8 & 146 & 206 & $41 \%$ & $2475 \%$ \\
\hline Twitter & 0 & 92 & 146 & $59 \%$ & $*$ \\
\hline YouTube & 13 & 34 & 135 & $297 \%$ & $938 \%$ \\
\hline MySpace & 26 & 9 & 25 & $178 \%$ & $-4 \%$ \\
\hline Blogs & 15 & 29 & 45 & $55 \%$ & $200 \%$ \\
\hline Flickr & 0 & 9 & 39 & $333 \%$ & $*$ \\
\hline E-surveys & 24 & 7 & 48 & $586 \%$ & $100 \%$ \\
\hline E-petitions & 10 & 3 & 20 & $567 \%$ & $100 \%$ \\
\hline E-newsletter & 42 & 78 & 104 & $33 \%$ & $148 \%$ \\
\hline Total I average \% & $\mathbf{2 7 5}$ & $\mathbf{5 6 4}$ & $\mathbf{9 4 2}$ & $\mathbf{6 7 \%}$ & $\mathbf{2 4 3 \%}$ \\
\hline
\end{tabular}

* Figures not available as no use was recorded in 2007.

E-surveys and e-petitions appear to have made a comeback after losing popularity in 2010, but this is misleading in terms of interactivity as most were basic proformas with limited user content able to be entered. Beyond the high incidence of these features of politicians' Web sites, 2013 was a visual election with posting of photographs on Flickr and videos on YouTube being the fastest growing forms of social media content. Facebook, Twitter and YouTube remained the most popular social media overall as in 2010, although Twitter use increased more than Facebook, as the latter approaches market saturation (see 'Politicians on Facebook'). Myspace made an apparent resurgence, but this was because the relaunched Myspace retained old accounts, which mostly remain unchanged since 2007. Blogs continued to be published by almost one quarter of sitting politicians (45), more than a 50 per cent increase on the number blogging in 2010.

\section{Personal Web sites}

Of the almost 200 politicians studied, 91 per cent had an 'official' personal Web site (i.e., one that they established or approved) and 13 per cent had Web sites designed and hosted by their political party, as well as the Australian Parliament House (www.aph.gov.au) Web page provided for all federal members of parliament. Interestingly, 14 per cent of sitting members did not provide links to any other sites from their official aph.gov.au page.

Overwhelmingly, politicians' personal Web sites were Web 1.0 in terms of their design and architecture - i.e., primarily focussed on one-way distribution of information to visitors, such as biographies, lists of political achievements, speeches and questions delivered in Parliament. Many were also heavily media rather than voter orientated, with 'media centres', 
'newsrooms' and media/news releases. Opportunities for interactivity were low to nonexistent on most, except for online subscription forms for newsletters and online contact details for the politician. Less than half of politicians' sites studied provided their e-mail address for direct contact, with 48 per cent providing only a Web contact form and 4 per cent offering no opportunity to connect electronically with the politician.

\section{Politicians on Facebook}

During the 2013 election 81 per cent of sitting members of parliament had either a Facebook profile or page, or both, compared with just over 70 per cent in 2010. This analysis included Facebook profiles which allow friending and posting of comments, as well as official pages which allow likes, talking about, and posting of comments. Unofficial community pages not under the control of the politician or political party and fake sites were excluded. Most politicians use Facebook pages for electoral engagement and campaigning, as these open to view without becoming a friend and have no limit on numbers, while a few allowed citizens to become Facebook friends. The volume of friends, likes and talking abouts ${ }^{1}$ on politicians' Facebook profiles and pages, reported in Table 2, increased substantially from 2010 when the highest number of likes was less than 70,000 for then Prime Minister Julia Gillard and Kevin Rudd had less than 50,000 likes and Tony Abbott less than 15,000. The youngest member of the Australian parliament Wyatt Roy reached the Facebook limit of 5,021 friends during the campaign and fellow Liberal Joe Hockey was approaching the limit with pending friend requests.

Table 2. The 'top 20' politicians on Facebook by number of friends, likes and talking abouts during the 2013 federal election campaign.

\begin{tabular}{llllllr}
\hline & No. of friends ${ }^{2}$ & \multicolumn{3}{c}{ No. of likes } & \multicolumn{2}{l}{ No. talking about } \\
\hline 1 & Wyatt Roy & 5,021 & Tony Abbott & 249,357 & Tony Abbott & 117,742 \\
\hline 2 & Joe Hockey & 5,015 & Kevin Rudd & 123,618 & Kevin Rudd & 67,986 \\
\hline 3 & Julie Bishop & 4,998 & Malcolm Turnbull & 28,452 & Adam Bandt & 15,312 \\
\hline 4 & Tony Burke & 3,595 & Adam Bandt & 24,951 & Malcolm Turnbull & 6,638 \\
\hline 5 & George Christensen & 3,575 & Bronwyn Bishop & 15,022 & Larissa Waters & 6,176 \\
\hline 6 & Warren Snowdon & 2,953 & Cory Bernardi & 10,286 & Bronwyn Bishop & 4,767 \\
\hline 7 & Lisa Singh & 2,858 & Christine Milne & 8,481 & Cory Bernardi & 4,262 \\
\hline 8 & Mathias Cormann & 2,384 & Tanya Plibersek & 8,002 & Wayne Swan & 3,621 \\
\hline 9 & Dennis Jensen & 2,276 & Christopher Pyne & 7,887 & Sarah Hanson-Young & 3,567 \\
\hline 10 & Claire Moore & 2,155 & Sarah Hanson-Young & 7,410 & Christine Milne & 3,458 \\
\hline 11 & Kelvin Thomson & 2,132 & Mark Dreyfus & 6,894 & Tanya Plibersek & 2,842 \\
\hline 12 & Joel Fitzgibbon & 1,999 & Bob Baldwin & 6,666 & Kate Ellis & 2,766 \\
\hline 13 & Amanda Rishworth & 1,966 & Wayne Swan & 6,622 & Anthony Albanese & 2,503 \\
\hline 14 & Brendan O'Connor & 1752 & Bill Shorten & 6,191 & Steve Georganas & 2,401 \\
\hline 15 & Andrew Southcott & 1,694 & Steve Georganas & 5,606 & Doug Cameron & 2,282 \\
\hline 16 & Sharman Stone & 1,655 & Larissa Waters & 5,120 & Rachel Siewert & 2,182 \\
\hline 17 & lan Macdonald & 1,571 & Kate Ellis & 4,912 & David Bradbury & 2,045 \\
\hline 18 & Stephen Jones & 1,529 & Janelle Saffin & 4,400 & Janelle Saffin & 1,925 \\
\hline & & & & &
\end{tabular}




\begin{tabular}{lllllll}
\hline 19 & Sean Edwards & 1,485 & Chris Bowen & 4,146 & Anna Burke & 1,640 \\
\hline 20 & David Bushby & 1,462 & Andrew Wilkie & 4,143 & Wyatt Roy & 1,504 \\
\hline
\end{tabular}

\section{Politicians on Twitter}

More than three-quarters (76 per cent) of the 191 sitting members studied had a Twitter account, compared with 45 per cent of sitting members during the 2010 Australian federal election, with just 24 per cent not on Twitter compared with 51 per cent who were not on Twitter in 2010. However, the style and purpose of tweeting varied widely as will be discussed under 'Qualitative findings'.

The 'top 20' most active politicians on Twitter are shown in Figure 1. Compared with the 2010 election campaign, more politicians tweeted more, although the most tweets by any politician in the 2013 campaign was 277 by the Liberal Senator Matthias Cormann, compared with Liberal MP Malcolm Turnbull's 439 tweets in the final three weeks of the 2010 election campaign. Second to Cormann on Twitter was Labor's Andrew Leigh with 180 tweets, followed by the ALP's Anthony Albanese with 160 tweets and the Greens Senator Christine Milne with 148 tweets. In 2013 nine of the 'top 10' most active politician on Twitter posted more than 100 tweets, as shown in Figure 1, compared with five 'centurion' tweeters during the 2010 campaign.

Turnbull was again active on Twitter with 134 tweets, but this made him the sixth most active of Twitter in 2013. Labor MP Kate Lundy and the Greens Senator Sarah Hanson-Young, who were in the 'top 10' in 2010, slipped back to $14^{\text {th }}$ and $17^{\text {th }}$ most active on Twitter in 2013, while the Liberal leader Tony Abbott increased his use of Twitter from just two tweets during the 2010 campaign to squeeze into the 'top 20' most active with 56 tweets. What politicians tweeted about is discussed under 'Qualitative findings'.

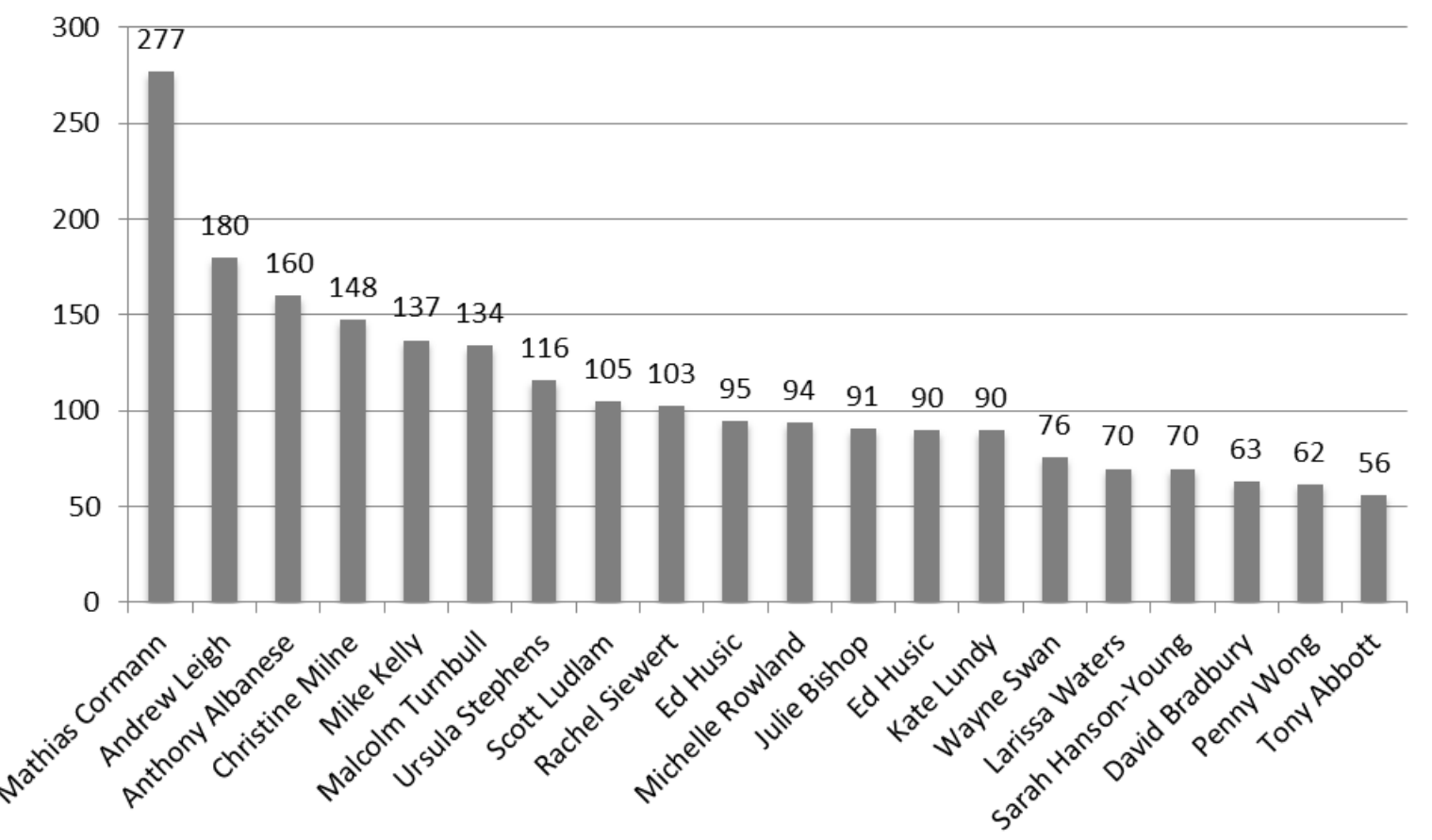

Figure 1. The 'top 20' politicians on Twitter by volume of tweets during the 2013 federal election campaign.

Twitter metrics that give some qualitative insight in relation to two-way interaction are the numbers of followers versus the numbers of others who politicians are following. Politicians typically seek to maximise their number of followers - their audience to whom they can 
speak - but often the number of others who they are following (i.e., potentially listening to) on Twitter is far fewer. This was clearly evident in the 2013 Australian federal election. Table 3 shows that the 20 most popular federal politicians on Twitter were following substantially fewer people than their number of followers. While this might be inevitable to some extent for popular public figures and elected officials in office, the disparity is marked. On average, the number of people who politicians were following was just 21 per cent of their number of followers. Some politicians were following as few as 1-2 per cent of their followers (e.g., former state Labor premier Bob Carr and Labor's Tanya Plibersek and Penny Wong; Liberal MP Julie Bishop and Greens Senator Christine Milne). Malcolm Turnbull who was the most interactive on Twitter in 2010 was following just 4 per cent of his number of followers and the Liberal's Cory Bernardi and/or his staff were following no one throughout the campaign.

Crosstab analysis of volume of tweets shown in Figure 1 with data on followers and following illustrates that high usage of social media does not necessarily equate to interaction, dialogue and citizen participation, with some of the most prolific Twitter users (e.g., Christine Milne and Malcolm Turnbull) seeking an audience and speaking frequently, but not listening in Twitter. (Note: Equating following to listening is a basic but useful metric, as the social media sites of politicians are usually operated not only by them personally, but by their campaign and electoral staff for market research and voter engagement.)

Table 3. The 20 politicians with the most followers and the number of Twitter users they were following.

\begin{tabular}{lrr}
\hline Politician & Followers & Following \\
\hline Kevin Rudd & $1,390,762$ & 422,793 \\
\hline Tony Abbott & 242,039 & 31,804 \\
\hline Malcolm Turnbull & 193,181 & 8,382 \\
\hline Joe Hockey & 91,266 & 1,027 \\
\hline Penny Wong & 51,092 & 384 \\
\hline Wayne Swan & 49,177 & 2,092 \\
\hline Bob Carr & 43,187 & 154 \\
\hline Julie Bishop & 41,387 & 452 \\
\hline Kate Ellis & 38,811 & 1,275 \\
\hline Anthony Albanese & 36,713 & 989 \\
\hline Adam Bandt & 35,928 & 16,627 \\
\hline Bill Shorten & 31,073 & 10,691 \\
\hline Christine Milne & 29,567 & 489 \\
\hline Tanya Plibersek & 28,303 & 112 \\
\hline Tony Burke & 28,178 & 11,593 \\
\hline Sarah Hanson-Young & 26,404 & 874 \\
\hline Chris Bowen & 19,879 & 726 \\
\hline Kate Lundy & 18,430 & 3,489 \\
\hline Scott Morrison & 16,492 & 677 \\
\hline Cory Bernardi & 14,623 & 0 \\
\hline & & \\
\hline
\end{tabular}




\section{Politicians on YouTube and other video sharing sites}

The former Labor leader Kevin Rudd dominated online video, posting 51 videos on YouTube during the campaign which gained more than 3 million views. The vast majority of these were of one video titled 'If you think homosexuality is an unnatural condition, I cannot agree' recorded from Rudd's appearance on the ABC program $Q \& A$ and uploaded to YouTube on 2 September 2013.This also demonstrates intermediation.

Significantly, the Liberal leader (now Prime Minister) Tony Abbott did not appear in the 'top 20' on YouTube by videos posted, subscribers or views. However, the Liberal Party YouTube channel had more subscribers and more than one million more views than the Australian Labor Party YouTube channel (see 'Political parties' sites'). This indicates that the Liberal strategy was to direct more communication through the party's sites than those of the leader or individual politicians.

\section{Politicians on other social media}

Posting of photographs increased substantially during the 2013 campaign compared with previous elections. The Liberals Tony Abbott, Malcolm Turnbull and Scott Morrison, along with Labor's Warren Snowdon, Kate Lundy and Kevin Rudd, dominated Flickr. Abbott (or his staff) posted more than 1,200 photos on Flickr and the 'top six' averaged more than 600 photos each. This and the significant increase in the number of videos posted and viewed on YouTube and other sites such as Vimeo highlighted 2013 as the visual election - although videos and photos were mostly information transmission with limited opportunities to comment.

The use of blogs by individual politicians has increased since 2010, but the majority of politicians' blogs featured articles by the hosts and few comments. It is not clear whether this is the result of heavy moderation (i.e., removing critical and unfavourable comments), or whether there were few comments. In either case, politicians' blogs are not sites of interactivity and engagement with citizens.

\section{Politicians' social media use by party, gender, and age}

As in 2010, there were no significant differences overall in social media use by politicians based on political party, gender or age, despite common assumptions that young people are more inclined to use social media than older people. The youngest sitting member in the Australian parliament, Wyatt Roy aged 23, was not among the 'top 10' or 'top 20' users of Twitter or the most followed or most liked on Facebook, although he did reach the 5,021 limit of Facebook friends.

\section{Political parties' sites}

Quantitative analysis of the sites of the two major political parties showed that the volume of videos posted on their respective YouTube channels, the number Facebook likes, the number of followers on Twitter and the number of citizens the major parties were following all increased substantially since 2010. In total, Labor almost doubled its number of video views from 1,247,009 in 2010 to more than 2 million in 2013, while the Liberal Party increased its total video views by six-fold from 639,111 in 2010 to almost 3.85 million. Similarly, the number of Labor and Liberal Twitter followers increased from 5,617 and 7,089 respectively in 2010 to almost 55,000 and almost 40,000 respectively in 2013.

Labor was more active on Twitter, posting 333 tweets during the final three weeks of the campaign, with almost 9,000 tweets in total and 54,559 followers by the date of the election, compared with the Liberals 353 tweets during the campaign, less than 7,000 tweets in total and 39,641 followers. However, the Liberal Party was more active and popular on Facebook 
with 27 Wall posts and more than 40,000 comments during the election, compared with Labor's 11 Wall posts and 15,680 comments. The Liberal Party's 200,000 plus Facebook likes also outstripped Labor's 165,000.

Blogging and custom-built Web sites have lost favour with the political parties, with the Labor Party blog and Labor Think Tank being closed and Labor Connect being moved from a specialist Web site to Facebook. This is probably a result of the amount of work involved in maintaining specialist Web sites, but also reflects a consolidation of the social media market with a number of dominant sites (namely, YouTube, Facebook and Twitter).

\section{Qualitative findings}

An overwhelming focus on politicians speaking in social media and a generalised lack of listening and two-way engagement is demonstrated, to some extent, in the disparity between the number of followers of politicians and the number of others who they are following on Twitter, as reported in detail in Table 3 and dramatically illustrated in Figure 2. (Note: Kevin Rudd, with 1,390,762 followers and following 422,793 has been removed from Figure 2 to allow the chart to illustrate the relatively low or near non-existent level of following across the remaining 19 of the 'top 20'.)

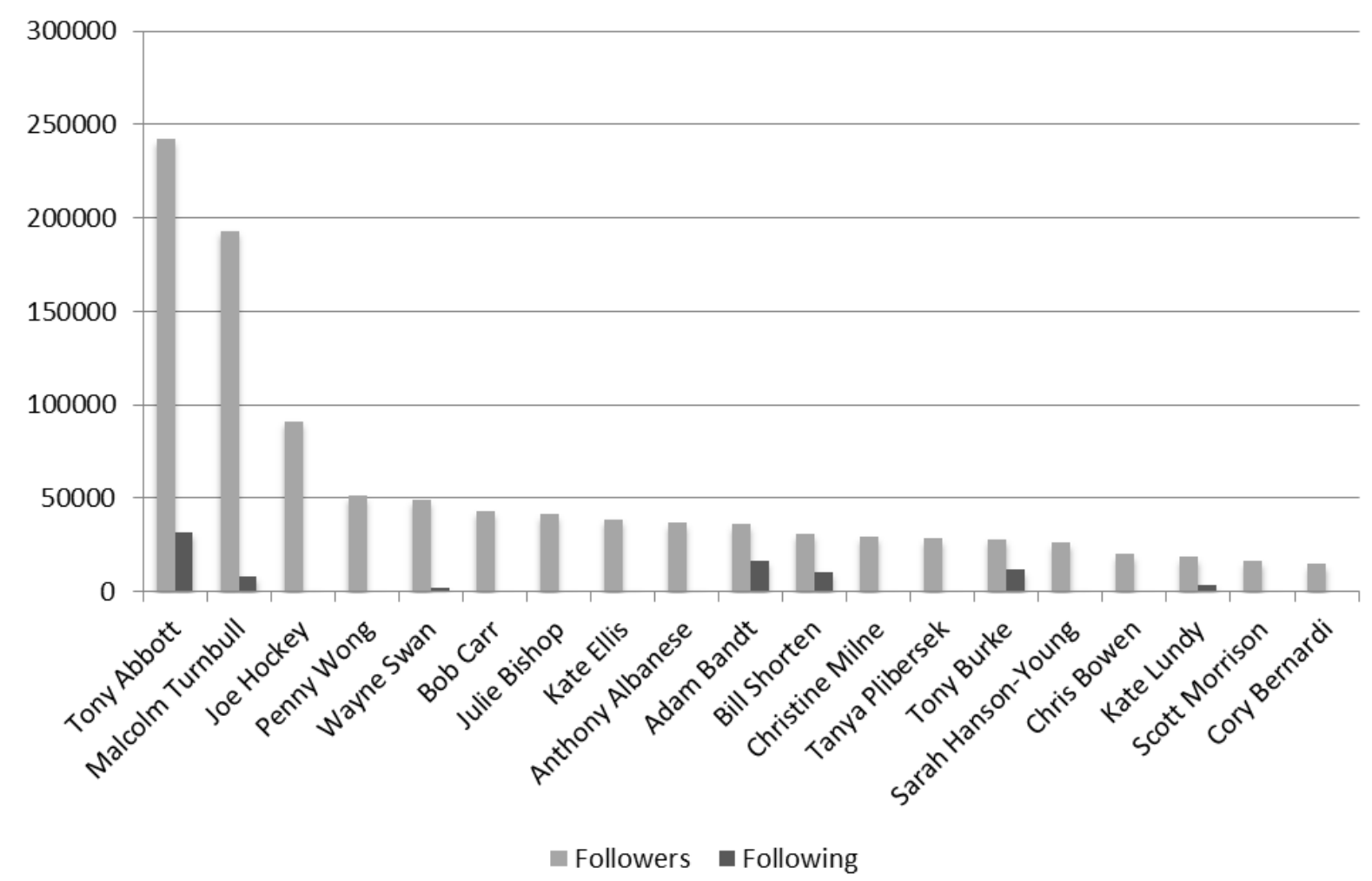

Figure 2. The number of followers of the most popular politicians on Twitter and the number of others who they were following.

More specifically, coding of 1,455 tweets posted by the 10 most active politicians on Twitter during the period of analysis revealed an overwhelming focus on broadcasting messages, rather than responding to others, answering questions and engaging in conversations. Qualitative analysis found 94.6 per cent of the tweets of the 10 most active politician tweeter were broadcasts, with just 5.4 per cent being direct messages or responses. 
While 'national political or social issues' were the main focus of tweets (27 per cent of the content) covering a wide range of issues, 'election slogans and promises' were the second most discussed topic (19 per cent). These typically comprised repetitive banal 'sloganeering', such as "Building the future” (Labor), "Better schools” (Labor) and 'Real change’ (Liberal). Most gained little response other than from 'dyed in the wool' party supporters.

Almost 10 per cent of tweets were 'attacks on an opponent's policy' and a further 6.4 per cent were 'attacks on opponents by name', giving a total of almost 800 highly negative tweets from just 10 politicians during the three weeks. Examples of negative attacking messages widely promulgated were 'against our national interests' (Liberal attacking Labor) and 'fraud band' and 'demolishing the NBN' (Labor against the Liberal National Broadband policy). Even the 23-year old Liberal MP Wyatt Roy, who is very much in the demographic most familiar with social media, tweeted only occasionally and negatively such as: 'Clive Palmer talking is about as appealing as Clive Palmer twerking, ${ }^{3}$ (Roy, 2013a). Roy tweeted only eight times, which included three retweets. Personal 'whereabouts reports' were the fourth most common type of tweets (7.1 per cent), such as 'I am at the ABC studios for an interview' or 'Today I am visiting the ... shopping centre'. All in all, the Twittersphere was not a positive or illuminating political space during the campaign, with discussion mostly confined to political rhetoric and clichés and almost entirely comprised of one-way transmission of politicians' messages.

The main issues discussed on Twitter by the 'top 10' most prolific politician users were budget costings and economics (135 mentions), the National Broadband Network (91 mentions), engaging with and responding to the public' (56 mentions) and sport and betting (46 mentions, which were mainly unrelated to the election or politics). Carbon trading, health, school and tertiary education and asylum seekers and refugees were mentioned in just 3 per cent of tweets; climate change in just 2 per cent of tweets; and Indigenous issues, lesbian, gay, and bisexual and transgender (LGBT) issues, women, poverty and food and agriculture were mentioned in just 1 per cent of Twitter discussion by the leading politician tweeters. Despite 56 tweets about engaging with and responding to the public, there was little engaging and responding in the social media analysed.

\section{Conclusions}

While the volume of social media use increased in the 2013 Australian federal election compared with previous elections, in terms of dialogue, conversation, responses, answering questions and listening to others' comments - key affordances of social media - the 2013 Australian election was not only not an advancement, but it was a step backwards compared with 2010 when 47.5 per cent of tweets by the 10 most active politicians on Twitter were responses and direct messages to others and 52.5 per cent were broadcast messages. Interactivity on incumbent politicians' and major political party blogs also declined in 2013 compared with 2010, with some containing no comments and some blogs, such as the official Labor Party blog being closed down. While the volume of social media use by the politicians and the major political parties studied has increased by almost two and a half times since the 2007 election, political communication remains 'politics 1.0'. (See Table 4 which presents a summary of the coding of the tweets of the 10 most active politicians on Twitter.)

This analysis of use of social media by incumbent politicians and major parties during the 2013 Australian federal election shows that what Blumler and Kavanagh (1999) called the 'third age of political communication' remains nascent and even illusory. Their prediction that control of messages would slip from the grasp of mass media producers and that technologies of interactive communication would give voice to citizens and create a more 
open participatory public sphere was unrealised in the 2013 Australian federal election in which Web sites and social media were used by most politicians and political parties as just another channel for one-way transmission of their campaigning messages.

Some studies suggest that this is to be expected (e.g., Stromer-Galley, 2000a). Hence, the enduring research question 'so what' can and should be asked? Does it matter that incumbent politicians and major political parties use social media for one-way dissemination of information? Based on studies of the perceptions and attitudes of citizens towards the way democratic politics is practiced in major developed countries (Coleman, 2013; Couldry, 2010: 49), and the perceptions of young people in particular (Bennett, 2008; Bennet et al., 2011; Fenton, 2012), the answer would appear to be yes.

While emerging forms of self-actualising and more personalised political participation by citizens, particularly young people, and new forms of 'political consumerism' and 'consumer activism' are taking full advantage of social media (Xenos et al., 2014: 155) and deserve further focus, it is nevertheless important to continue to monitor elected political representatives and major political parties and critically analyse how they use media to communicate and interact with citizens, given they are central political actors in the public sphere. This analysis supports the view of Loader et al. (2014: 145) that a significant recalibration of political institutions and traditional practices is necessary to maintain relevance and legitimacy. As Australia's youngest politician Wyatt Roy wrote in The Australian newspaper shortly after the 2013 election, 'voters utilising social and online media will expect a lot more of their politicians' (2013b: 12). 
Table 4. Qualitative content analysis of tweets by the 'top 10' most prolific politician tweeters.

\begin{tabular}{|c|c|c|c|c|c|c|c|c|c|c|c|c|}
\hline Politician & $\begin{array}{l}\text { Mathias } \\
\text { Cormann }\end{array}$ & $\begin{array}{l}\text { Andrew } \\
\text { Leigh }\end{array}$ & $\begin{array}{l}\text { Anthony } \\
\text { Albanese }\end{array}$ & $\begin{array}{l}\text { Christine } \\
\text { Milne }\end{array}$ & $\begin{array}{l}\text { Mike } \\
\text { Kelly }\end{array}$ & $\begin{array}{l}\text { Malcolm } \\
\text { Turnbull }\end{array}$ & $\begin{array}{l}\text { Ursula } \\
\text { Stephens }\end{array}$ & $\begin{array}{l}\text { Scott } \\
\text { Ludlam }\end{array}$ & $\begin{array}{l}\text { Rachel } \\
\text { Siewert }\end{array}$ & $\begin{array}{l}\text { Ed } \\
\text { Husic }\end{array}$ & TOTAL & $\%$ \\
\hline Party & Liberal & Labor & Labor & Greens & Labor & Liberal & Labor & Greens & Greens & Labor & & \\
\hline No. of tweets & 277 & 180 & 160 & 148 & 137 & 134 & 116 & 105 & 103 & 95 & 1,455 & \\
\hline \multicolumn{13}{|l|}{ Coding categories: } \\
\hline $\begin{array}{l}\text { National political or } \\
\text { social issue }\end{array}$ & 276 & 127 & 146 & 147 & 134 & 128 & 116 & 104 & 100 & 94 & 1,372 & $27.0 \%$ \\
\hline $\begin{array}{l}\text { Local political or } \\
\text { social issue }\end{array}$ & 1 & 1 & 14 & 1 & 3 & 6 & & 1 & 3 & 1 & 31 & $0.6 \%$ \\
\hline $\begin{array}{l}\text { Whereabouts } \\
\text { reports }\end{array}$ & 3 & 39 & 73 & 33 & 13 & 75 & 30 & 58 & 20 & 19 & 363 & $7.1 \%$ \\
\hline $\begin{array}{l}\text { Personal information } \\
\text { or feeling }\end{array}$ & 0 & 1 & 9 & 7 & 1 & 29 & 26 & 11 & 3 & 8 & 95 & $1.9 \%$ \\
\hline $\begin{array}{l}\text { Elections slogans } \\
\text { and promises }\end{array}$ & 235 & 31 & 139 & 100 & 70 & 65 & 43 & 168 & 27 & 95 & 973 & $19.1 \%$ \\
\hline $\begin{array}{l}\text { Attack on opponent } \\
\text { by name }\end{array}$ & 177 & 16 & 18 & 38 & 25 & 9 & 12 & 13 & 14 & 4 & 326 & $6.4 \%$ \\
\hline $\begin{array}{l}\text { Attack on opponent's } \\
\text { policy }\end{array}$ & 197 & 52 & 27 & 23 & 61 & 14 & 40 & 31 & 12 & 10 & 467 & $9.2 \%$ \\
\hline TOTAL & 1,166 & 447 & 586 & 497 & 444 & 460 & 383 & 491 & 282 & 326 & 5,082 & $100.0 \%$ \\
\hline Direct message & 0 & 4 & 14 & 0 & 0 & 0 & 0 & 0 & 0 & 61 & 79 & $5 \%$ \\
\hline Broadcast tweet & 277 & 176 & 146 & 148 & 137 & 134 & 116 & 105 & 103 & 34 & 1,376 & $94.6 \%$ \\
\hline Sending links & 18 & 96 & 25 & 93 & 94 & 120 & 59 & 92 & 72 & 22 & 691 & $47.5 \%$ \\
\hline
\end{tabular}




\section{References}

Anderson, C. 2006, The Long Tail, Hyperion, New York, NY.

Bennett, W. 2008, 'Changing citizenship in the digital age', in W. Bennett (ed.), Civic Life Online, MIT Press. Cambridge, MA, pp. 1-24.

Bennett, W. Wells, C. and Freelon, D. 2011, 'Communicating civic engagement: Contrasting models of citizenship in the youth Web culture', Journal of Communication, vol. 61, no 5, pp. 835-56.

Blumler, J. and Kavanagh, D. 1999, 'The third age of political communication: Influences and features', Political Communication, vol. 16, pp. 209-30.

Boler, M. (ed), 2008. Digital Media and Democracy: Tactics in Hard Times, MIT Press, Cambridge, MA.

Bucy, E. 2004, 'Interactivity in society: Locating an elusive concept', Information Society, vol. 20, no. 5, pp. 373-83.

Carpentier, N. 2007, 'Participation, access and interaction: Changing perspectives', in V. Nightingale and T. Dwyer (eds), New Media Worlds: Challenges for Convergence, Oxford University Press, South Melbourne, pp. 214-30.

Carpentier, N. 2011, Media and Participation: A Site of Ideological Democratic Struggle, Intellect, Chicago, IL.

Chen, P. 2008, 'Candidates' new media use in the 2007 Australian national election', in F. Papandrea and M. Armstrong (eds), Record of the Communications Policy and Research Forum 2008, Network Insight, Sydney, pp. 62-78.

Coleman, S. 2013, How Voters Feel. Cambridge University Press, New York, NY.

Couldry, N. 2010, Why Voice Matters: Culture and Politics after Neoliberalism, Sage, London and Thousand Oaks, CA.

Cover, R. 2004, 'New media theory: Electronic games, democracy and reconfiguring the authoraudience relationship', Social Semiotics, vol. 13, no. 2, pp. 173-91.

Curran, J. 2012, 'Reinterpreting the internet', in J. Curran, N. Fenton and D. Freedman (eds), Misunderstanding the Internet, Routledge, Abingdon Oxon, UK, pp. 3-33.

Dahlgren, P. 2009, Media and Political Engagement: Citizens, Communication and Democracy, Cambridge University Press, New York.

Fenton, N. 2012, 'The internet and social networking', in J. Curran, N. Fenton and D. Freedman (eds.), Misunderstanding the Internet, Routledge, Abingdon Oxon, UK, pp. 123-48.

Flew, T. 2014, New Media: An Introduction, $4^{\text {th }}$ edn, Oxford University Press, South Melbourne, Vic.

Flew, T. and J. Wilson. 2008, 'Citizen journalism and political participation: The YouDecide 2007 project and the 2007 Australian federal election', Australian Journal of Communication, vol. 35, no. 2, pp. $17-37$.

Gandy, O. 2002, 'The real digital divide: Citizens versus consumers', in L. Lievrouw and S. Livingstone (eds), The Handbook of New Media, Sage, London, pp. 448-600.

Gibson, R. and Cantijoch, M. 2011, 'Comparing online elections in Australia and the UK: Did 2010 finally produce the internet election?' Communication, Politics \& Culture, vol. 44, no. 2, pp. 4-17.

Gibson, R. Cantijoch, M. and Ward, S. 2010, 'Citizen participation in the e-campaign', in R. Gibson, A. Williamson and S. Ward, The Internet and the 2010 election: Putting the Small ' $p$ ' Back in Politics, Hansard Society, London, UK, pp. 5-16.

Gibson, R. Lusoli, W. and Ward, S. 2008, 'The Australian public and politics online: Reinforcing or reinventing representation', Australian Journal of Political Science, vol. 43, pp. 111-31.

Gibson, R. and McAllister, I. 2008, 'Online campaigning in the 2007 Australian election: Did the Web deliver votes?' Paper presented to the annual meeting of the American Political Science Association, Boston, MA, August.

Gibson, R. and Ward, S. 2008, 'Introduction: E-politics - the Australian experience', Australian Journal of Political Science, vol. 43, March, pp. 1-11.

Gibson, R. Williamson, A. and Ward, S. 2010, The Internet and the 2010 Election: Putting the Small ' $p$ ' Back in Politics, Hansard Society, London.

Goot, M. 2008, 'Is the news on the internet different? Leaders, frontbenchers and other candidates in the 2007 Australian election’, Australian Journal of Political Science, vol. 43, pp. 99-110. 
Habermas, J. 1989, The Structural Transformation of the Public Sphere, Polity, Cambridge, UK. (Original work published 1962)

Habermas, J. 2006, 'Political communication in media society: Does democracy still enjoy an epistemic dimension? The impact of normative theory on empirical research', Communication Theory, vol. 16, no. 4, pp. 411-26.

Harrison, T. and Barthel, B. 2009, 'Wielding new media in Web 2.0: Exploring the history of engagement with the collaborative construction of media products', New Media \& Society, vol. 11, no. 1 \& 2, pp. 155-78.

Howley, K. 2007, 'Community media and the public sphere', in E. Devereux (ed.), Media Studies: Key Issues and Debates, Sage, London, UK, pp. 342-60.

Hwang, S. 2013, 'The effect of Twitter use on politicians' credibility and attitude towards politicians', Journal of Public Relations Research, vol. 25, no. 3, pp. 246-58.

Jenkins, H. 2006, Convergence Culture: Where Old and New Media Collide, New York University Press, New York, NY.

Kaplan, R. and Haenlein, M. 2010, 'Users of the world, unite! The challenges and opportunities of social media', Business Horizons, vol. 53, no. 1, pp. 59-68.

Lin, C. 2013, 'Social media politics: The use of Facebook and the 2012 Taiwan presidential election', unpublished doctoral thesis, Macquarie University, Sydney.

Loader, B. Vromen, A. and Xenos, M. 2014, 'The networked young citizen: Social media, political participation and civic engagement', Information, Communication and Society, vol. 17, no. 2, pp. 143-50.

Macnamara, J. 2008, 'The internet and the public sphere: The 2007 Australian e-electioneering experience’, Media International Australia, vol. 129, November, pp. 7-19.

Macnamara, J. 2011, 'Pre and post-election 2010 online: What happened to the conversation?' Communication, Politics, Culture, vol. 44, no. 2, pp. 18-36.

Macnamara, J. 2014, The $21^{\text {st }}$ Century Media (R)evolution: Emergent Communication Practices, $2^{\text {nd }}$ edn, Peter Lang, New York.

Macnamara, J. and Kenning, G. 2011, 'E-electioneering 2010: Trends in social media use in Australian political communication’, Media International Australia, vol. 139, pp. 7-22.

Macnamara, J. Sakinofsky, P. and Beattie, J. 2012, 'E-lectoral engagement: Maintaining democratic participation through social media', report for the Australian Electoral Commission, Australian Centre for Public Communication, University of Technology Sydney, May, http://www.aec.gov.au/About_AEC/research/caber/1c.htm

McAllister, I. 2002, Civic Education and Political Knowledge in Australia, papers on Parliament 38, Department of the Senate, Australian Government, Canberra.

McMillan, S. 2002, 'Exploring models of interactivity from multiple research traditions: Users, documents and systems', in L. Lievrouw and S. Livingstone (eds), Handbook of New Media, Sage, London, pp. 163-82.

McNair, B. 2006, Cultural Chaos: Journalism, News and Power in a Globalised World, Routledge, New York.

Media Monitors 2008, 'E-election media analysis report', Sydney, NSW, January.

Merholz, P. 2005, 'It's not about the technology', http://www.peterme.com/archives/000560.html

Mouffe, C. 1999, 'Deliberative democracy or agonistic pluralism', Social Research, vol. 66, no. 3, pp. 745-58.

Naughton, J. 2011, 'Yet another Facebook revolution: why are we so surprised?’ The Guardian, 23 January, http://www.guardian.co.uk/technology/2011/jan/23/social-networking-rules-ok

Neuman, W. 2006, Social Research Methods: Qualitative and Quantitative Approaches, $6^{\text {th }}$ edn, Pearson Education, Boston, MA.

O’Reilly, T. 2005, 'What is web 2.0: Design patterns and business models for the next generation of software', O’Reilly blog, 30 September, http://www.oreillynet.com/pub/a/oreilly/tim/news/2005/09/30/what-is-web-20.html

Papacharissi, Z. 2007, 'The blogger revolution? Audiences as media producers', in M. Tremayne (ed.), Blogging, Citizenship and the Future of the Media, Routledge. New York, NY, pp. 21-38.

Rainie, L. Smith, A. Schlozman, K. Brady, H. and Verba, S. 2012, 'Social media and political engagement', Pew Internet \& American Life Project, Washington, DC, http://www.pewinternet.org/Reports/2012/Political-engagement.aspx 
Rosenstiel, T. and Mitchell, A. 2012, 'How the presidential candidates use the web and social media', Pew Research Center Project for Excellence in Journalism, Washington DC, http://www.journalism.org/analysis_report/how_presidential_candidates_use_web_and_social_me dia

Roy,W.2013a, @Wyatt_Roy_MP,Twitter,https://twitter.com/Wyatt_Roy_MP

Roy, W. 2013b, 'Politics must be more inclusive', The Australian, Commentary, 19 September, p. 12.

Scherer, M. 2012, 'Exclusive: Obama's 2012 digital fundraising outperformed 2008', TIME, 15 November, http://swampland.time.com/2012/11/15/exclusive-obamas-2012-digital-fundraisingoutperformed-2008

Schudson, M. 1998, The Good Citizen: A History of American Civic Life, The Free Press, New York, NY.

Schudson, M. 2003, 'Click here for democracy: A history and critique of an information-based model of citizenship', in H. Jenkins and D. Thorburn (eds), Democracy and New Media, MIT Press, Cambridge, MA, pp. 49-60.

Shoemaker, P. and Reese, S. 1996, Mediating the Message: Theories of Influences on Mass Media Content, Longman, White Plains, NY.

Siapera, E. 2012, Understanding New Media, Sage, London, UK and Thousand Oaks, CA.

Smith, P. 2013, 'Social media fails to fire up election', Australian Financial Review, 17 August, http://www.afr.com/p/technology/social_media_fails_to_fire_up_election_emr3mn4Sh7nouefeV MEpjP

Smith, A. and Rainie, L. 2008, ‘The internet and the 2008 election', Pew Internet \& American Life Project report, 15 June, Pew Research Center, Washington DC, http://www.pewinternet.org/PPF/r/252/report_display.asp

Stromer-Galley, J. 2000a, 'On-line interaction and why candidates avoid it', Journal of Communication, vol. 50, no. 4, pp. 111-32.

Stromer-Galley, J. 2000b, 'Democratising democracy: Strong democracy, US political campaigns and the internet', Democratization, vol. 7, no. 1, pp. 36-58.

Sydney Morning Herald, 2007, 'The YouTube election', 14 July, p. 23.

Vargas, J. 2008, 'Obama raised half a billion online’, Washington Post, 20 November, http://voices.washingtonpost.com/44/2008/11/20/obama_raised_half_a_billion_on.html

Vergeer, M. 2013, 'Politics, elections and online campaigning: Past, present ... and a peek into the future', New Media and Society, vol. 15, no. 1, pp. 9-17.

Woolgar, S. 2002, 'Five rules of virtuality', in Virtual Society? Technology, Cyberbole, Reality, Oxford University Press, Oxford, UK, pp. 1-22.

Xenos, M. and Moy, P. 2007, 'Direct and differential effects of the internet on political and civic engagement', Journal of Communication, vol. 57, no. 4, December, pp. 704-18.

Xenos, M. Vromen, A. and Loader, B. 2014, 'The great equaliser? Patterns of social media use and youth political engagement in three advanced democracies', Information, Communication, Society, vol. 17, no. 2, pp. 151-167.

* Jim Macnamara PhD, FAMI, CPM, FPRIA, FAMEC is Professor of Public Communication at the University of Technology Sydney, a position he took up in 2007 after a 30-year professional career spanning journalism, public relations and media research. He is the author of 15 books including The $21^{\text {st }}$ Century Media (R)evolution: Emergent Communication Practices ( Peter Lang, New York, 2010, $2^{\text {nd }}$ edition 2014).

* Gail Kenning PhD is a Research Associate in the Faculty of Arts and Social Sciences at the University of Technology Sydney and a practicing artist specialising in digital media and data visualisation. She is engaged in experimental research into uses of digital media for social interaction and creativity and the implications for social capital, health and wellbeing. 


\section{Reference:}

Macnamara, J. and Kenning, G. 2014, 'E-electioneering 2007-2013: Trends in online political campaigns over three elections', Media International Australia, [in print August].

1 'People talking about this', abbreviated to 'talking about', is a new Facebook feature introduced in October 2012 that records the number of unique visitors who interact with a page in a seven-day period in some way, such as liking a page, posting a comment, sharing, tagging, 'RSVPing' to an event, etc.

2 The number of Facebook friends shown is based on data that is publicly viewable, which is dependent on acceptance of friend requests and the privacy setting of the Facebook user.

3 A type of dance, which involves shaking and wobbling of the hips up and down. 